\title{
MTBP promotes migration and invasion by regulation of ZEB2-mediated epithelial-mesenchymal transition in lung cancer cells [Corrigendum]
}

Pan B, Han H, Wu L, et al. Onco Targets Ther. 2018;11: 6741-6756.

On page 6741, the authors' affiliation details were incorrect. The correct details are shown here.

Bo $\operatorname{Pan}^{1}$

Haibo $\mathrm{Han}^{2}$

Lina $\mathrm{Wu}^{3}$

Ying Xiong ${ }^{1}$

Jianzhi Zhang ${ }^{1}$

\author{
Bin Dong ${ }^{3}$ \\ Yue Yang ${ }^{1}$ \\ Jinfeng Chen ${ }^{1}$
}

${ }^{1}$ Key Laboratory of Carcinogenesis and Translational Research (Ministry of Education/Beijing), Department of Thoracic Surgery II, Peking University Cancer Hospital \& Institute, Beijing, China; ${ }^{2}$ Department of Biobank, Peking University Cancer Hospital \& Institute, Beijing, China; ${ }^{3}$ Department of Central Laboratory, Peking University Cancer Hospital \& Institute, Beijing, China
OncoTargets and Therapy

\section{Publish your work in this journal}

OncoTargets and Therapy is an international, peer-reviewed, open access journal focusing on the pathological basis of all cancers, potential targets for therapy and treatment protocols employed to improve the management of cancer patients. The journal also focuses on the impact of management programs and new therapeutic agents and protocols on

\section{Dovepress}

patient perspectives such as quality of life, adherence and satisfaction. The manuscript management system is completely online and includes a very quick and fair peer-review system, which is all easy to use. Visit http://www.dovepress.com/testimonials.php to read real quotes from published authors. 